\title{
Investigating EFL Teachers' Conceptions and Literacy of Formative Assessment: Constructing and Validating an Inventory
}

\author{
Hossein Khodabakhshzadeh \\ English Department, Torbat-e-Heydarieh Branch, Islamic Azad University, Torbat-e- \\ Heydarieh, Iran, kh.phdtbt2015@gmail.com
}

\section{Zahra Kafi}

English Department, Torbat-e-Heydarieh Branch, Islamic Azad University, Torbat-eHeydarieh, Iran,zahra.kafi.p@gmail.com

\section{Mansooreh Hosseinnia}

English Department, Torbat-e-Heydarieh Branch, Islamic Azad University, Torbat-eHeydarieh, Iran, mansoorehhossinnia@yahoo.com

The present study aimed at constructing a formative assessment inventory for assessing EFL instructors' conception and literacy about the issue under study. Therefore, 302 male and female Iranian EFL teachers took part in the study in a random way to fill out the researcher made questionnaire. The first draft of the scale consisted of two main categories, tacit (theoretical) and practical knowledge along with 26 items. After employing EFA and CFA, it was revealed that the questionnaire consists of a high validity. Also, for having a better fit for model and construct validity, some of the items were omitted out of the first draft of the questionnaire because of having low loadings. In addition, the reliability of the questionnaire was gained by running Cronbach's Alpha which was .855. At the end, the results for EFA revealed that the two factors can be regarded as the two constructs that the test claims to measure, namely: (1) Tacit knowledge, and (2) practical knowledge. Among the 17 items of the "Tacit knowledge category" five items $(9,14,15,16$, and 17) were excluded because of loadings less than .30 .

Keywords: formative assessment, conception, literacy, SEM, EFL teachers, EFA, CFA

\section{INTRODUCTION}

Assessment has a major role in teaching and learning. Today, with the rise of post method pedagogy ideologies, formative assessment has been replaced summative assessment and has become more under consideration by most teachers. In other words, 'assessment of learning' has shifted to 'assessment for learning', where assessment is in support of learning (Black \& Wiliam, 1998). Formative assessment consists of

Citation: Khodabakhshzadeh, H., Kafi, Z., \& Hosseinnia, M. (2018). Investigating EFL Teachers' Conceptions and Literacy of Formative Assessment: Constructing and Validating an Inventory. International Journal of Instruction, 11(1), 139-152. https://doi.org/10.12973/iji.2018.11110a 
'feedback focused on helping students to improve [and] sharing criteria of quality' (James \& Pedder, 2006, p. 110). So, formative assessment is helping students to find their learning path and improvement. According to Black et al. (2011), formative assessment has three-way paths: from students to teacher, from teacher to students, and from student to student.

Hutchinson \& Hayward (2005) in their study presented a complete examination of the establishment of the Assessment is for Learning plan in Scotland. This article includes matters in developing and implementing instructional approaches that have applications beyond the Scottish framework. In another study, Hayward (2007) investigated the relationship between curriculum and assessment in Scotland context. It specifies curricular and assessment arrangements at two stages of study of 3-14 and post-14 and it also presents a comprehensive discussion of the strengths and weaknesses of development of a consistent assessment structure and presents a valuable analysis of the Scottish Survey of Achievement and its function within the Assessment is for learning plan.

Formative assessment is a new concept in Iran and most of the teachers have not enough literacy of this kind of assessment. The majority of teachers still prefer the paper and pencil tests and summative ones. Many studies have been done to examine effectiveness of formative assessment. However, scare studies have been implemented for examining literacy of teachers about formative assessment. Therefore, because of scarcity of studies with this point of view and also with the importance of formative assessment in teaching and learning, this study aims to construct and validate a formative assessment scale to measure the knowledge of teachers in this important issue in education on the basis of theoretical and practical parts.

\section{Review of the Literature and Theoretical Bachground}

Formative assessment is considered to be a vital part of an instructor's job. That is formative assessment is a true, dynamic process for placing the teacher's teaching and students' learning into a sheer practice to continuously observe what goes right or wrong in a classroom setting. Therefore, "formative assessment is a constantly occurring process, a verb, a series of events in action, not a single tool or a static noun"(the NCTE executive committee, 2013). Instructors are supposed to select the most appropriate formative assessment based on the situation and context of teaching and learning which could be at times observations, conversations, student self-evaluations, and artifacts of learning (Serafini, 2010).

Regarding formative assessment and its effects on learning a study has been done by Fontana \& Fernandes (1994) in which 246 students whose ages ranged between 8 and 9 and 108 older students with ages between 10 and 14 participated in the study in a random way. The main focus of the assessment project was on regular, mostly daily, self-assessment by the pupils. It contained teaching them to understand both the learning objectives and the assessment criteria, giving the participants opportunities to choose learning activities and using tasks which provided them with the scope to assess their own learning outcomes. After the post test was conducted in both groups, the results 
revealed that students in the experimental group could outperform the ones in the control group for the sake of utilizing formative assessment techniques. Moreover, some review studies have been done by researchers such as Crooks (1988) and Black (1993b) which have revealed some disadvantages regarding the formative assessment done by teachers in classroom settings. Among all it could be mentioned that classroom evaluation practices generally encourage artificial, rote learning, concentrating on recall of isolated details, usually items of knowledge which students soon afterwards forget. In addition, instructors do not usually review the assessment questions that they use and do not discuss them critically with their peers, so there so little reflection on what is being assessed. Also, the grading function is mostly often over-emphasized and the learning function as a matter of fact under-emphasized (As mentioned in Black et al., 1998). On the other hand, studies done in the realm of formative assessment have pinpointed the idea that most teachers are rarely willing to practice their colleagues' proved assessment results in their classes (Cizek et al., 1995; Hall et al., 1997). And the studies which have been conducted have had their main focus on low level aims such as recalling therefore leaving issues such as speculation and critical reflection rather untouched in formative assessment by instructors (Stiggins et al., 1989; Schilling et al., 1990; Pijl, 1992).

On the other hand, researches handled in the realm of teachers' conceptions and literacy of formative assessment, it has been repeatedly mentioned that instructors who make use of formative assessment techniques in their classrooms are much successful in dealing with various students and the different needs they have. Thus, students who come to be aware of assessment techniques and evaluations "learn how to learn" which leads to an increased level of learning and understanding in pupils for the sake of applying adaptive teaching and learning techniques. Besides, one of the shortcomings of formative assessment is that the researches done along with the results gained are mostly context based and cannot be generalized to all teaching circumstances therefore being viewed as irrelevant to the business of teaching (Centre for Educational Research and Innovation, 2008).

Experimental and field studies in which instructors had a focus on teachers' employing formative assessment in classroom settings have obtained some similar results which were in line with increasing students' intrinsic motivation, self-esteem, academic selfconcept, causal attributions, and learning (Mischo and Rheinberg, 1995). Also, Black and Wiliam (1998a) have handled a review of literature about the results of the studies done related to formative assessment to see whether it increases academic standards in classroom settings or not. It was revealed that students who were exposed to formative assessment methods and techniques had a better achievement than the ones who were evaluated just through a final paper and pencil test at the end of the course. In addition, formative assessment was extremely helpful for low-achieving students (As cited in Boston, 2002).

Regarding teachers' literacy towards formative assessment a study has been conducted by Lam (2015) to investigate the overall language assessment training landscape in five Hong Kong teacher education institutions. It mainly attempted to explore the extent to which two assessment courses may facilitate or inhibit the improvement of pre-service 
teachers' language assessment literacy in one teacher education institution. The outcome indicated that language assessment training in Hong Kong has still remained inadequate and selected language assessment courses are yet unable to bridge the theory-practice gap within the assessment reform context. Moreover, another research has been conducted to find out about the formative feedback used by instructors and its impacts on students' learning outcome and bridging the gap they have in their learning. For reaching the purpose of the study, classroom observations and focus group discussions were employed among primary school ESL teachers in Malaysia. The results illustrated that using feedback systematically to support learning is so rare and "teachers are not aware of strategies to implement formative feedback to improve students' learning and use the information in their future instruction" (Sardareh, 2016).

Regarding formative assessment, scare studies have been implemented for examining literacy of teachers about formative assessment. Therefore, because of scarcity of studies with this point of view and also with the importance of formative assessment in teaching and learning, this study aims to construct and validate a formative assessment scale to measure the knowledge of teachers in this important issue in education on the basis of theoretical and practical parts. Also, developing such questionnaire can at least make the EFL instructors aware of their knowledge and activities they apply in their classrooms as forms/kinds of formative assessment. So, this questionnaire comprises two factors: the tacit knowledge of formative assessment and practical knowledge of formative assessment. The first factor means what teachers know about formative assessment. The second factor means how teachers implement formative assessment in their classroom.

\section{METHOD}

\section{Participants}

A sample of $302 \mathrm{EFL}$ (English as a Foreign Language) school instructors from Khorasan Razavi Province, Iran, took part in the study based on convenience sampling. 80 of the participants were from Torbat-e- Heydarieh city and the others were from Mashhad, Khaf, and Doolaat Abad cities. The participants' age ranged between 27 to 50 . The instructors mostly held B.A. and then M.A. degrees in TEFL.

\section{Instruments}

\section{Formative Assessment Inventory}

The Formative Assessment Inventory is a researcher made questionnaire which is in English. It consists of three parts which aim at eliciting the EFL instructors' conception and literacy about formative assessment. The first part of the questionnaire is related to the participants' demographic information. The second part targeted the teachers' idea, knowledge, and belief about formative assessment (17 items) that they were asked to choose one of the five choices for each item ranging from "a great deal" to "not much". And the last section provided the participants with some formative assessment activities/examples ( 9 items) to see how far the activities the instructors perform in their classes are based on formative assessment rules and principals. Similar to the second section, they were supposed to choose among the five options provided for each 
statement ranging from a great deal to not much. In addition, the questionnaire possessed a high construct validity and a high reliability,.855, after running EFA, CFA, cross-validation, and Cronbach's alpha respectively.

\section{Procedure}

In order to construct the Formative Assessment Inventory, the researchers followed two clear cut steps: first designing the test and second checking its reliability and validity.

For designing the test, the researchers followed all the procedures and steps provided by Dornyei (2003) of how to construct and administer a questionnaire. Also, Exam Regulations for State Education was used to find more exact information about how formative assessment is looked upon and what the teachers are supposed to do for such kind of evaluation/assessment within their classrooms as well as the amount of mark it has and its importance and all the other related factors. After delving into all the related scientific articles along with the previous aforementioned procedures the items of the questionnaire were developed. For making sure that all the dimensions of formative assessment have been mentioned among the items in the questionnaire, checking content validity, the researchers asked some experienced EFL teachers in the field to go through the items carefully and suggest any further ideas about the issue under investigation. As a result, some of the items were reworded for clarity and some of the items which elicited a similar point were omitted. The final outcome of the questionnaire was 26 items each having 5 options to be chosen by the participants, ranging from "a great deal" to "not much". In addition, the questionnaire consisted of two main categories/factors: Tacit/theoretical knowledge and Practical knowledge about formative assessment.

For estimating the validity of the questionnaire or to say the analysis of the results better, except for the procedures mentioned above, SEM was employed, EFA and CFA. Besides, the items were scored according to the Likert type scale of five points. It has to be stated that negatively worded items were reverse scored so that a total positivelyoriented score could be achieved. Also, the validity of the inventory was assessed afterwards through running Cronbach's Alpha. The results regarding the reliability and validity of the questionnaire are completely discussed in the Results section of the paper.

It's worth mentioning that after employing EFA and CFA to check for the scale's validity as well as the construct validity six of the items were omitted from the first draft of the questionnaire because of having low loadings. As a result, the final scale consisted of: Tacit/theoretical category: items 1-12, and Practical knowledge category: items 13-20.

\section{FINDINGS}

The validation of the scale was conducted in three main steps: (1) exploratory factor analysis (EFA) with principal component analysis and varimax rotation, (2) confirmatory analysis to determine the robustness of the factor structure on one randomly determined half of the dataset (training); (3) cross-validation using multigroup invariance testing between half of the dataset (training) and the unused second half of the dataset (testing). 
In order to assure the construct validity of the test, exploratory factor analysis (EFA) with principal component analysis and varimax rotation was run. The 26 items of formative assessment scale were subjected to EFA and the suitability of data for factor analysis was assessed. The KMO was .749, exceeding the recommended value of .6 and Bartlett's Test of Sphericity reached statistical significance, supporting the factorability of the correlation matrix. Principle component analysis revealed the presence of two components with eigenvalues exceeding 1 . Moreover, the highest loading for each item was considered as the appropriate factor for that item. Results of the EFA can be seen in Table 1

Table 1 Rotated Component Matrix for formative assessment Scale

\begin{tabular}{|c|c|c|}
\hline & Com & \\
\hline & 1 & 2 \\
\hline n6 & .689 & \\
\hline n5 & .688 & \\
\hline $\mathrm{n} 4$ & .664 & \\
\hline $\mathrm{n} 2$ & .640 & \\
\hline $\mathrm{n} 1$ & .609 & \\
\hline $\mathrm{n} 12$ & .606 & \\
\hline n3 & .567 & \\
\hline n13 & .566 & \\
\hline n8 & .530 & \\
\hline n7 & .524 & \\
\hline n10 & .510 & \\
\hline n11 & .467 & \\
\hline n25 & & .729 \\
\hline n26 & & .684 \\
\hline n23 & & .675 \\
\hline n24 & & .667 \\
\hline n22 & & .639 \\
\hline n21 & & .634 \\
\hline n20 & & .586 \\
\hline n19 & & .470 \\
\hline
\end{tabular}

As Table 1 shows, the two factors can be regarded as the two constructs that the test claims to measure, namely: (1) Tacit/theoretical knowledge, and (2) Practical knowledge. Among the 17 items of the Tacit knowledge five items $(9,14,15,16$, and 17) were excluded because of loadings less than .30. Question 6 had the highest loading and question 11 had the lowest loading in the first factor. Among the nine items of the practical knowledge only one item (18) was excluded because of loadings less than 30 . Question 25 had the highest loading and question 19 had the lowest loading in the second factor. 
Following this, confirmatory factor analysis (CFA) was run to see whether the ten factors solution obtained in EFA can be confirmed. For this purpose, CFA was run to assess the fit of the model on one random half of the sample. To come up with a statistically significant theoretical model, some necessary criteria are presented in the Table 2.

Table 2

Model-Fit Criteria and Acceptable Fit Interpretation

\begin{tabular}{lll}
\hline Model-Fit Criterion & Acceptable Level & Interpretation \\
\hline Chi-square & Tabled $\chi^{2}$ value & $\begin{array}{l}\text { Compares obtained } \chi^{2} \text { value with tabled } \\
\text { value for given } d f\end{array}$ \\
\hline Goodness-of-fit index (GFI) & 0 (no fit) to 1 (perfect fit) & $\begin{array}{l}\text { Value close to } .90 \text { or } .95 \text { reflect a good } \\
\text { fit }\end{array}$ \\
\hline $\begin{array}{l}\text { Root-mean-square error of } \\
\text { approximation (RMSEA) }\end{array}$ & .05 to .08 & Value of .05 to .08 indicate close fit \\
\hline $\begin{array}{l}\text { Normed fit index (NFI) } \\
\text { 0 (no fit) to 1 (perfect fit) }\end{array}$ & $\begin{array}{l}\text { Value close to .90 or .95 reflects } \\
\text { a good model fit }\end{array}$ \\
\hline
\end{tabular}

Note. Adapted from “A Beginner's Guide to Structural Equation Modelling," by R. E.Schumacker, \& R. G. Lomax, 2010, Routledge: NY, p.76.

"In general, if any of these indices are above .90 , the rule of thumb is that there is a recommendation from the indices that there is model fit, pending examination of the $\chi 2$ statistic and model interpretability" (Kunnan ,1988, p. 307). Table 3. illustrates the criteria used for the present study below.

Table 3

Model-Fit Indices for formative assessment Scale

\begin{tabular}{lllllll}
\hline & $\mathrm{X}^{2}$ & $\mathrm{df}$ & $\mathrm{X}^{2} / \mathrm{df}$ & $\mathrm{GFI}$ & $\mathrm{CFI}$ & RMSEA \\
\hline Acceptable fit & & & $<3$ & $>.90$ & $>.90$ & $<.08$ \\
Model & 293.546 & 169 & 1.737 & .910 & .903 & .079 \\
\hline
\end{tabular}

According to Table 3, the CFA confirmed the structure of formative assessment scale. 


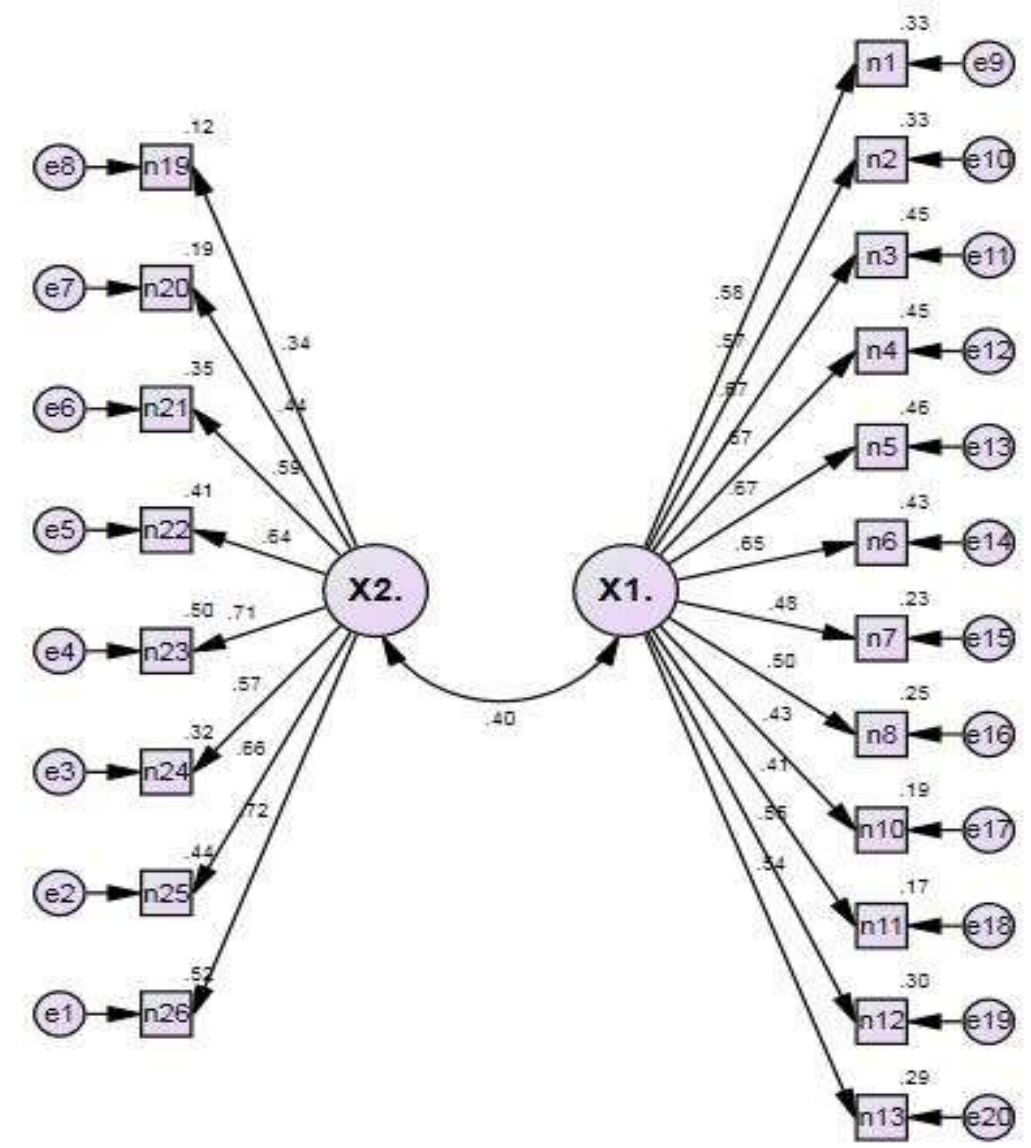

Figure 1

CFA model for formative assessment scale. Factor $1=$ Tacit/theoretical knowledge; factor $2=$ Practical knowledge

As Figure 1 shows, from 17 items of factor 1 twelve items were remained and from nine items of the factor 2 eight items were remained.

In addition, the CFA was cross validated on the second half (151 participants) using multi-group invariance testing. Our analysis has equal numbers of cases in each group because little is known about the possible effect of unequal group sizes on results obtained from a multiple group SEM analysis. The training participants $(N=151)$ and the testing participants $(N=151)$ subsets were compared to test the robustness of the two-factor model.

The results of multi-group comparisons indicated that the two-factor structure on the 20 items was equally robust in both random sets. In addition, the two sets of samples proved factorially invariant $(\mathrm{X} 2 / \mathrm{df}=2.891, \mathrm{RMSEA}=.047, \mathrm{CFI}=91, \mathrm{GFI}=.93)$. 
Moreover, to examine the reliability of the scale, Cronbach's alpha was used. The reliability coefficient was .855 for total scale, which shows the scale enjoys high reliability (See Table 4). It should also be added that because six items were deleted, the numbering of the items in this questionnaire changed in the final draft of the questionnaire as follows: Tacit/theoretical knowledge category (items 1-12), and practical knowledge category (items 13-20) (See Appendix for formative assessment scale).

Table 4

The Reliability Indices of formative assessment Questionnaire

\begin{tabular}{llc}
\hline Subscale & Item No. & Cronbach alpha \\
\hline X1 & $1-12$ & .846 \\
X2 & $13-20$ & .806 \\
Total Scale & $1-20$ & .855 \\
\hline
\end{tabular}

\section{Descriptive statistics}

Number of participants, minimum and maximum scores, means and standard deviations of the subscales used in the study are presented in Table 5.

Table 5 presents descriptive statistics of two subscales of formative assessment scale, i.e., factor1 and factor2.

Table 5

Descriptive Statistics of two subscales of formative assessment scale, i.e., x1 and x2

\begin{tabular}{llllll}
\hline & N & Minimum & Maximum & Mean & Std. Deviation \\
\hline X1 & 302 & 26 & 45 & 37.780 & 5.03 \\
X2 & 302 & 15 & 30 & 24.102 & 3.79 \\
Total & 302 & 48 & 78 & 60.37 & 6.87 \\
Valid N (listwise) & 302 & & & & \\
\hline
\end{tabular}

The possible range of score for the $\mathrm{x} 1$ is between 12 and 48 , for $\mathrm{x} 2$ is between 8 and 32 and for total scale is between 20 and 80 . As it can be seen in Table 5 the mean score of the learners' report in $\mathrm{x} 1$ was 37.780 , in $\mathrm{x} 2$ was 24.102 , and in total scale was 60.37 . In addition, the table shows that number of learner participant was 302 .

\section{DISCUSSION AND CONCLUSION}

A researcher made Formative Assessment Inventory was constructed with the aim of eliciting the Iranian EFL instructors' ideas about how formative assessment is done at schools and the quality through which it is administered/performed. Therefore, the scale targeted the teachers' idea, knowledge, and belief about formative assessment. As well as providing the participants with some formative assessment activities/examples to see how far the activities that the instructors perform in their classes are based on formative assessment rules and principals. Besides, the first draft of the questionnaire consisted of 26 items along with two factors/categories, tacit knowledge and practical knowledge. For checking the validity of the questionnaire EFA and CFA were applied. The results for EFA revealed that the two factors can be regarded as the two constructs that the test claims to measure, namely: (1) Tacit knowledge, and (2) practical knowledge. Among 
the 17 items of the "Tacit knowledge category" five items $(9,14,15,16$, and 17) were excluded because of loadings less than .30. Question 6 had the highest loading and question 11 had the lowest loading in this factor. Among the nine items of "Practical knowledge category" only one item (18) was excluded because of loadings less than .30 . Question 25 had the highest loading and question 19 had the lowest loading in the second factor. Moreover, CFA was run to assess the fit of the model. The outcome confirmed the structure of formative assessment scale.

Consequently, the final results of the analysis led to omitting 6 items from the first draft of the questionnaire. Thus, the numbering of the items in the inventory changed in the final draft of the questionnaire as: Tacit knowledge category (items 1-12), and Practical Knowledge category (items 13-20). Moreover, to examine the reliability of the scale, Cronbach's alpha was used. The reliability coefficient was .855 for total scale. Also for the first and second factors, reliabilities of .846 and .806 were obtained respectively.

As it was mentioned elsewhere in the article formative assessment is considered to be interwoven with an instructor's job. That is formative assessment is a true, dynamic process for placing the teacher's teaching and students' learning into a sheer practice to continuously observe what goes right or wrong in a classroom setting. Therefore, "formative assessment is a constantly occurring process, a verb, a series of events in action, not a single tool or a static noun, shifting from assessment of learning' to 'assessment for learning'. Thus, instructors are supposed to select the most appropriate formative assessment based on the situation and context of teaching and learning which could be at times observations, conversations, student self-evaluations, and artifacts of learning (Serafini, 2010). Also, according to Black et al. (2011), formative assessment has three-way path: from students to teacher, from teacher to students, and from student to student. Moreover, the results of this study and the focus which has been placed towards formative assessment can help teachers stay away and be aware of, Crooks (1988) and Black (1993b), artificial, rote learning, concentrating on recall of isolated details as misused formative assessment activities. In addition, instructors do not usually review the assessment questions that they use and do not discuss them critically with their peers, so there is so little reflection on what is being assessed. Also, the grading function is mostly often over-emphasized and the learning function as a matter of fact under-emphasized (As mentioned in Black et al., 1998). Thus, developing such questionnaire can at least make the EFL instructors aware of their knowledge and activities they apply in their classrooms as forms/kinds of formative assessment.

\section{Recommendations for Further Research}

At the end, the limitations of the present study could be used as some suggestions for further study and research. As the data is gathered from just EFL school instructors from just Khorasan Razavi province, another study could be done by gathering data from other parts of the country as well as having participants from English language schools. Also, a kind of cause and effect study could be conducted to find out that whether having courses about assessment and more specifically formative assessment will affect teachers' teaching, testing and assessing or not. And then constructing a questionnaire which is out of the teachers' experience throughout the course. 


\section{REFERENCES}

Black, P.J. (1993b). Formative and summative assessment by teachers. Studies in Science Education, 21, 49-97.

Black, P., \& Wiliam, D. (1998a). Assessment and classroom learning. Assessment in

Education, 5(1), 7-74.

Black, P., \& Wiliam, D. (1998). Assessment and classroom learning. Assessment in

Education: Principles, policy \& practice, 5(1).

Black, P., Wilson, M., \& Yao, S-Y. (2011). Road maps for learning: A guide to the navigation of learning progressions. Measurement Journal, 9, 71-123.

Boston, C. (2002). The concept of formative assessment. ERIC Digest. Centre for Educational Research and Innovation. (2008). Assessment for Learning Formative Assessment.

Centre for Educational Research and Innovation. (2008). https://www.google.com/search?q=Centre+for+Educational+Research+and+Innovation.

Cizek, G. J., Fitzgerald, S. M., \& Rachor, R. E. (1995). Teachers' assessment practices:

Preparation, isolation and the kitchen sink. Educational Assessment, 3, 159-179.

Crooks, T. J. (1988). The impact of classroom evaluation practices on students. Review of Educational Research, 58, 438-481.

Dornyei, Z. (2003). Questionnaires in second language research: Construction, administration, and processing.

Fontana, D., \& Fernandes, M. (1994) Improvements in mathematics performance as a

consequence of self-assessment in Portuguese primary school pupils. British Journal of Educational Psycology, 64, 407-417.

Hall, K., Webber, B., Varley, S., Young, V., \& Dorman, P. (1997). A study of teacher assessment at key stage 1. Cambridge Journal of Education, 27, 107-122.

Hayward, E. L. (2007). Curriculum, pedagogies and assessment in Scotland: The quest for social justice. "Ah kent yir faither." Assessment in Education 14(2), 251-268.

Hutchinson, C., \& Hayward, L. (2005). The journey so far: Assessment for learning in Scotland. Curriculum Journal 16(2), 225-248.

Kunnan, A. J. (1988). An introduction to structural equation modelling for language assessment research. Language Testing, 15, 295-332.

James, M., \& Pedder, D. (2006). Beyond method: Assessment and learning practices and values. The Curriculum Journal, 17(2), 109-138. 
Lam, R. (2015). Language assessment training in Hong Kong: Implications for language assessment literacy. Language Testing, 32(2), 169-197.

Mischo, C., \& Rheinberg, F. (1995). Erziehungsziele von lehrern und individuelle Bezugsnormen der leistungsbewertung. Zeitschrift fur Padagogische Psychologie, 9, 139- 151.

PIJL, S. J. (1992). Practices in monitoring student progress. International Review of Education, 38,117-131.

Sardareh, S. A. (2016). Formative feedback in a Malaysian primary school ESL context. Malaysian Online Journal of Educational Sciences, 4 (1), 1-8.

Schilling, M., Hargreaves, L., Harlen, W., \& Russell, T. (1990). Written tasks. London, Paul Chapman.

Serafini, F. (2010). Classroom reading assessments: More efficient ways to view and evaluate your learners. Portsmouth, NH: Heinemann.

Stiggins, R. J., Grisword, M. M., \& Wikelund, K. R. (1989). Measuring thinking skills through classroom assessment. Journal of Educational Measurement, 26, 233-246.

The NCTE Executive Committee (2013). Formative assessment that truly informs instruction. National Council of Teachers of English. 


\section{Appendix}

\section{Formative Assessment Inventory}

\section{Dear Instructor:}

The present questionnaire is constructed in order to investigate the instructors' opinions about how formative assessment is done/implemented as well as its quality. Therefore, your honest, exact answers will help us in the realm of formative assessment and how to educate instructors for it. In addition, your answers/information will be confidential.

\section{Demographic Information:}

Name of the institution:

\section{Gender:}

Educational degree:
City:

Age:

Years of Teaching Experience:

Educational Major:

\begin{tabular}{|c|c|c|c|c|c|}
\hline Part 1 & Questions & $\begin{array}{c}\text { Not } \\
\text { much }\end{array}$ & Little & $\begin{array}{l}\text { Some- } \\
\text { what }\end{array}$ & \begin{tabular}{l|l} 
Much & $\begin{array}{l}\text { A Great } \\
\text { deal }\end{array}$
\end{tabular} \\
\hline 1 & To what extends to you believe in formative assessment? & & & & \\
\hline 2 & $\begin{array}{l}\text { To what extends do you think formative assessment can } \\
\text { be implemented? }\end{array}$ & & & & \\
\hline 3 & $\begin{array}{l}\text { To what extends do you consider the score gained out of } \\
\text { formative assessment reliable and worthy? }\end{array}$ & & & & \\
\hline 4 & $\begin{array}{l}\text { To what extends do you consider teachers' } \\
\text { independence/authority as a crucial issue in formative } \\
\text { assessment? }\end{array}$ & & & & \\
\hline 5 & $\begin{array}{l}\text { To what extends do you think formative assessments } \\
\text { affects teachers' independence/authority in teaching? }\end{array}$ & & & & \\
\hline 6 & $\begin{array}{l}\text { To what extends do you think formative assessment } \\
\text { helps teachers' authority/independence in the realm of } \\
\text { assessment in general? }\end{array}$ & & & & \\
\hline 7 & $\begin{array}{l}\text { To what extends do you think the method of } \\
\text { implementing formative assessment affects teaching and } \\
\text { learners' learning? }\end{array}$ & & & & \\
\hline 8 & $\begin{array}{l}\text { To what extends do you think that parents' familiarity } \\
\text { with the method of implementing formative assessment } \\
\text { affects its true/correct implementation? }\end{array}$ & & & & \\
\hline 9 & $\begin{array}{l}\text { To what extends do you think there must be a significant } \\
\text { relation between formative assessment score and } \\
\text { summative assessment score? }\end{array}$ & & & & \\
\hline 10 & $\begin{array}{l}\text { To what extends do you evaluate/assess your learners' } \\
\text { knowledge through various stages of formative } \\
\text { assessment? }\end{array}$ & & & & \\
\hline 11 & $\begin{array}{l}\text { To what extends do you think that making learners } \\
\text { aware of the process of formative assessment by the } \\
\text { teacher is important? }\end{array}$ & & & & \\
\hline 12 & $\begin{array}{l}\text { To what extends do you think that making learners' } \\
\text { parents aware of the process of formative assessment by } \\
\text { the teacher is important? }\end{array}$ & & & & \\
\hline Part 2 & $\begin{array}{l}\text { Please determine to what extent the carried-out activities } \\
\text { are based on formative assessment, after studying the } \\
\text { following examples. }\end{array}$ & & & & \\
\hline
\end{tabular}

International Journal of Instruction, January $2018 \bullet$ Vol.11, No.1 


\begin{tabular}{|l|l|l|l|l|l|l|}
\hline 13 & $\begin{array}{l}\text { The learners are asked to listen carefully to the } \\
\text { pronunciation of English vocabularies and to distinguish } \\
\text { their probable problems. }\end{array}$ & & & & & \\
\hline 14 & $\begin{array}{l}\text { The math teacher aggregates the learners and asks them } \\
\text { to present the solution of the problem as a report, after } \\
\text { the presentation of a problem to each group. }\end{array}$ & & & & & \\
\hline 15 & $\begin{array}{l}\text { The teacher files all the learners' activities, including } \\
\text { written, oral, and practical ones. }\end{array}$ & & & & & \\
\hline 16 & $\begin{array}{l}\text { After teaching, the teacher observes the learners' } \\
\text { activities at different situations every few weeks. }\end{array}$ & & & & & \\
\hline 17 & $\begin{array}{l}\text { After teaching, the teacher observes the learners' } \\
\text { activities at different situations every few weeks, and } \\
\text { records his/her exact observation as a list. }\end{array}$ & & & & & \\
\hline 18 & $\begin{array}{l}\text { After teaching, the teacher observes the learners' } \\
\text { activities at different situations every few weeks, and } \\
\text { records his/her exact observation as a list. Finally, he/she } \\
\text { evaluates the learners' performance based on his/her } \\
\text { devised ordinal measurement. }\end{array}$ & & & & & \\
\hline 19 & $\begin{array}{l}\text { After teaching, the teacher asks the learners to observe, } \\
\text { record, and evaluate his/her performances and activities } \\
\text { by presenting a list to the learners every week. }\end{array}$ & & & & & \\
\hline 20 & $\begin{array}{l}\text { The teacher makes a list of the procedure of his/her } \\
\text { formative assessment during the year and presents it to } \\
\text { the administrators, parents, and also learners. }\end{array}$ & & & & & \\
\hline
\end{tabular}

International Journal of Instruction, January $2018 \bullet$ Vol.11, No.1 